\title{
Potential Development of Milkfish Gelatin (Chanos chanos) Bound Cellulose and Starch as Food and Pharmaceutical Additives
}

\author{
I Ismail ${ }^{1}$, M N Djide 2 , Latifah R 3 , M A Manggau 4 , N Hamzah 5 , A Ahmad ${ }^{6}$ \\ ${ }^{1,5}$ Departement of Pharmacy, Faculty of Medicine and Health Science, \\ Universitas Islam Negeri Alauddin Makassar, Indonesia. 92113 \\ 1,2,3,4, Departement of Biofarmacetic and Pharmaceutic, Faculty of Pharmacy, \\ Universitas Hasanuddin, Indonesia \\ ${ }^{6}$ Departement of Hadis, Faculty of Ushuluddin and Philosophy, \\ Universitas Islam Negeri Alauddin Makassar, Indonesia. 92113 \\ \{isriany.ismail@uin-alauddin.ac.id ${ }^{1}$, natsirdj@yahoo.com², mariantimanggau@unhas.ac.id ${ }^{4}$, \\ nursalam.hamzah@gmail.com ${ }^{5}$ \\ arifuddin.ahmad@uin-alauddin.ac.id $\left.{ }^{6}\right\}$
}

\begin{abstract}
This study aims to improve the quality of gelatin produced from milkfish scales to be used as food and pharmaceutical additives through the binding of milkfish gelatin with cellulose and starch. Gelatin obtained from milkfish scales mixed at temperatures between $70-90^{\circ} \mathrm{C}$ with cellulose (GS) and starch (GA), namely hydroxypropyl methylcellulose (HPMC), methylcellulose (CMC), corn starch, potato starch and cassava starch with comparison of gelatin: cellulose/starch for groups I, II, III, IV, V, VI respectively (4.5:0.5); (4:1); $(3.5: 1.5) ;(3: 2) ;(2.5: 2.5)$ and $(2: 3)$. The modified gelatin was observed for interacting between molecules by FTIR and analyzed the viscosity profile, as well as the potential utilization for food and pharmaceutical additive products. The results showed that the modified gelatin resulted in interacting carboxylic, hydroxyl, and amine groups from gelatin and cellulose/starch was characterized by a shift in wavenumber. The GS modification results in better gel quality than GA. The viscosity profile of GS increases with increasing cellulose levels. $\mathrm{GS}_{\mathrm{I}} \&$ $\mathrm{GS}_{2}$ has the potential to be used as a thickener for liquid food and pharmaceutical preparations (syrup, suspension, and emulsion) and semi-solids (gel, cream, paste) while $\mathrm{GS}_{3}, \mathrm{GS}_{4}, \mathrm{GS}_{5}$, and $\mathrm{GS}_{6}$ can be used as a controlled release drug matrix and drug delivery system.
\end{abstract}

Keywords: Fish Gelatin, Milkfish, Modified Gelatin, Cellulose, Starch, Viscosity

\section{Introduction}

The need for gelatin for the food and pharmaceutical industry has increased from year to year because gelatin is one ingredient that is often used as an additive to improve elasticity, 
consistency, and stability of preparations [1], [2].

Most of the commercial gelatin which is 326,000 tons of global gelatin production per year comes from cow bones (29.4\%), bone, skin and soft tissue of pigs (41-46\%) [1]. A number of issues have arisen and come to the attention of producers in recent years, namely the need for halal products in countries with a predominantly Muslim population, including countries with high Muslim consumer visits [1], [3]. Therefore it is necessary to develop gelatin sources other than those from other mammals or non-mammals that have quality according to the standards of use in the food and pharmaceutical industry.

The quality of gelatin is influenced by the extraction process, including the choice of type and concentration of acid or base $(\mathrm{pH})$, temperature, duration of soaked, and method of drying [3]. The difference in extraction temperature had a different effect $(\mathrm{P}>0.05)$ on the value [2], gel strength, and viscosity of the skin gelatin of chicken feet [4]. The low quality of fish gelatin causes limited to use. Fish gelatin has a gel strength and melting temperature $\left(12-13^{\circ} \mathrm{C}\right)$ lower than gels from mammalian gelatin. The low quality of gel from fish gelatin is caused by the amount and type of protein contained. Fish collagen compared to mammalian collagen, in general, is characterized by a relatively high percentage of serine and glycine, and a low percentage of hydroxyproline and proline. To be used in the food and pharmaceutical industry, the gel must have good functional properties, including the ability to form a thermo reversible gel, texture, thickness, and water binding capacity. Therefore, efforts are needed to improve the quality of the functional properties of the gel so that it can be used in the pharmaceutical industry and other industries[5].

Improved quality of fish gelatin may have the potential to be used more than just as a food additive, but also for pharmaceutical preparations and the drug delivery system matrix [6], [7]. The limitations of fish gelatin properties can be improved by several approaches, including the crosslinking of gelatin [8]-[12]. Modification of gelatin and the combination of gelatin with other biomaterials has demonstrated system flexibility and is a challenge in the discovery of specific, targeted, and biodegradable controlled released preparation systems. Composite films obtained from soybean-protein isolate (SPI) and cod gelatin were reported that all films were produced are translucent in appearance, but the yellowish color increased with increasing proportions of the soybean proteins [12]. Gelatin has demonstrated the ability to vary from its intrinsic properties and allows it to be designed into various carrier systems, namely microparticles and nanoparticles. Gelatin microparticles can function as carriers to cells and conductors for large bioactive molecules. Gelatin nanoparticles can be used for intravenous delivery or drug delivery to the brain. Gelatin fibers resulting from cross-links that have a ratio of surface area and volume allow can trap molecules and diffuse into blood vessels. Gelatin can also be developed into bioadhesive polymers that can control the release of drugs to treat pain and wound healing [13].

Gelatin is a hydrophilic polymer. The development of gelatin into a drug carrier, especially hydrophilic drugs is very necessary, considering that hydrophilic drugs have cross-membrane barriers so that absorption is low and results in low drug bioavailability.

Based on the description above, the quality of gelatin originating from fish still needs to be improved beyond just getting results and meeting food ingredients standards, but the quality can be further improved to meet pharmaceutical industry standards and can be used as raw materials for pharmaceutical preparations and matrices delivery system drug. Considering the results of the 
South Sulawesi aquaculture resources and the development of gelatin quality from the fish scales, the research will be conducted on the development of gelatin from the milkfish scales (Chanos Chanos) as pharmaceutical additives and matrices drug delivery system.

\section{Method}

Scales of milkfish (Chanos Chanos) were taken from the fish processing industry of PT Usaha Centraljaya Sakti, Makassar Industrial Area, South Sulawesi, Indonesia, distilled water $\left(\mathrm{H}_{2} \mathrm{O}\right)$, hydrochloric acid $(\mathrm{HCl})$, sodium hydroxide $(\mathrm{NaOH})$, Hydroxy Propyl Methyl Cellulose (HPMC), Carboxy Methyl Cellulose (CMC), starch namely potatoes, corns and cassava using Merck $^{\circledR}$ production

\section{Gelatin Extraction}

Gelatin extraction followed the procedure according to Boran, G.Regenstein, J. M.[14] with modification

Milkfish scales taken from the fish processing industry were cleaned with water, dried and stored in a freezer temperature of $-20^{\circ} \mathrm{C}$ until it is used.

\section{Pre-treatment}

Milkfish scales were soaked with $\mathrm{NaOH} 1 \mathrm{~N}$ solution for 1 hour at $30^{\circ} \mathrm{C}$ then filtered and washed 3 times with distilled water. Furthermore, soaked again with $\mathrm{HCl} 1$ Nsolution for 1 hour at $30^{\circ} \mathrm{C}$ then filtered. After that, the residues washed using distilled water until the $\mathrm{pH}$ is neutral.

\section{Extraction and Drying}

The residue from the pretreatment procedure was soaked in hot distilled water at $90^{\circ} \mathrm{C}$ for 8 hours and dried in the oven at $80^{\circ} \mathrm{C}$.

\section{Modification of Gelatin}

A total of 5 grams of a mixture with a ratio of gelatin and cellulose/starch respectively 4.5: $0.5,4: 1,4.5: 0.5,3.5: 1.5,3: 2,2.5: 2.5$, and $2: 3$ suspended in distilled water and sufficient to 200 $\mathrm{ml}$. The mixture was stirred for 30 minutes $(100 \mathrm{rpm})$ at $80^{\circ} \mathrm{C}$ until clear, followed by stirring for 30 minutes $750 \mathrm{rpm}$. The mixture was dried as a thin layer using an oven temperature of $80^{\circ} \mathrm{C}$.

\section{Characterization of gelatin modifications}

\section{Organoleptic}

Observation of color, smell, texture, and shape of gelatin modifications

\section{Interacting Molecules}

The modified gelatin was observed for interacting between molecules by FTIR (Thermo Scientific Nicolet iS10).

\section{Viscosity}

The $0.67 \%(\mathrm{w} / \mathrm{v})$ gelatin, gelatin modifications with cellulose/starch was completely dissolved separately in distilled water $\left(70^{\circ} \mathrm{C}\right)$, and the viscosity was measured using a viscometer (Ostwald) at $20^{\circ} \mathrm{C}$. The calculation using the formula:

$$
\begin{aligned}
& \begin{array}{l}
\text { Kinematic viscosity }\left(\mathrm{mm}^{2} / \mathrm{s}\right) \\
\left(\mathrm{mm}^{2} / \mathrm{s}^{2}\right)
\end{array} \\
& \begin{array}{l}
\text { Viscosity }(\mathrm{cP}) \\
(\mathrm{g} / \mathrm{mL}) \ldots \ldots \ldots \ldots \ldots \ldots \ldots \ldots \ldots \ldots \ldots \ldots \ldots \ldots \ldots \ldots \ldots
\end{array}
\end{aligned}
$$




\section{Viscosity profile}

Modified gelatin that showed good characteristics with optimum ratio was then measured of viscosity in several concentrations.

\section{Analysis Methods}

Viscosity profiles of gelatin modifications were illustrated graphically. Statistical analysis used the Analysis Variant (ANAVA) method. The comparison of the average used Duncan's multiple range tests to assess the difference in viscosity of each group using the IBM SPSS 22.00 application.

\section{Results and Discussion}

Modification of gelatin produced from milkfish scales is done by reacting gelatin with cellulose or starch by following the comparative design of the two polymers as shown in table 1 . The gelatin and polymer ratio (cellulose and starch) is designed by gradually increasing the polymer from cellulose or starch to observe that the improved characteristics of the modified gelatin did not originated from the presence of the polymer but from the result of chemical interactions between the gelatin and the polymers. Chemical interaction between gelatin and cellulose or starch was possible by the availability of functional groups in gelatin and the two polymers such as $\mathrm{NH}_{2}$ and $\mathrm{OH}$.

Table 1.Design Ratio Gelatin with Cellulose/Starch produced Gelatin Modifications

\begin{tabular}{|c|c|c|c|c|c|c|c|}
\hline \multirow{3}{*}{ No. } & \multirow{3}{*}{$\begin{array}{c}\text { Gelatin }(\%) \\
(\mathrm{w} / \mathrm{v})\end{array}$} & \multirow{2}{*}{\multicolumn{2}{|c|}{$\begin{array}{c}\text { Cellulose (Gs) } \\
(\%)\left({ }^{w} / v\right)\end{array}$}} & \multicolumn{3}{|c|}{$\operatorname{Starch}\left(G_{A}\right)(\%)\left({ }^{w} / v\right)$} & \multirow{3}{*}{$\begin{array}{l}\text { Ratio } \\
(5 \mathrm{~g})\end{array}$} \\
\hline & & & & \multirow[b]{2}{*}{$\begin{array}{c}\text { Potato } \\
\mathrm{G}_{\mathrm{AS}}\end{array}$} & \multirow[b]{2}{*}{$\begin{array}{c}\text { Cassava } \\
\mathrm{G}_{\mathrm{AK}}\end{array}$} & \multirow[b]{2}{*}{$\begin{array}{l}\text { Corn } \\
\mathrm{G}_{\mathrm{AM}}\end{array}$} & \\
\hline & & $\begin{array}{c}\mathrm{HPMC} \\
\mathrm{G}_{\mathrm{SH}}\end{array}$ & $\begin{array}{c}\mathrm{CMC} \\
\mathrm{G}_{\mathrm{SC}}\end{array}$ & & & & \\
\hline 1 & 90 & & & 10 & & & $4.5: 0.5$ \\
\hline 2 & 80 & & & 20 & & & $4: 1$ \\
\hline 3 & 70 & & & 30 & & & $3.5: 1.5$ \\
\hline 4 & 60 & & & 40 & & & $3: 2$ \\
\hline 5 & 50 & & & 50 & & & $2.5: 2.5$ \\
\hline 6 & 40 & & & 60 & & & $2: 3$ \\
\hline
\end{tabular}

The interaction between gelatin and the polymer is shown by IR spectra in Figure 5 . Interactions occur in the $\mathrm{NH} / \mathrm{NH} 2$ and $\mathrm{OH}$ groups through hydrogen bonds. The availability of hydroxyl groups in the cellulose used allows fast and stable interaction with the $\mathrm{NH} / \mathrm{NH} 2$ groups on gelatin which results in modified gelatin with better characteristics as shown in table 2 and figures 1-4. The characteristics shown by the gelatin modified with starch did not show any significant difference $(p>0.05)$ in the viscosity value between the gelatin and the modified results.
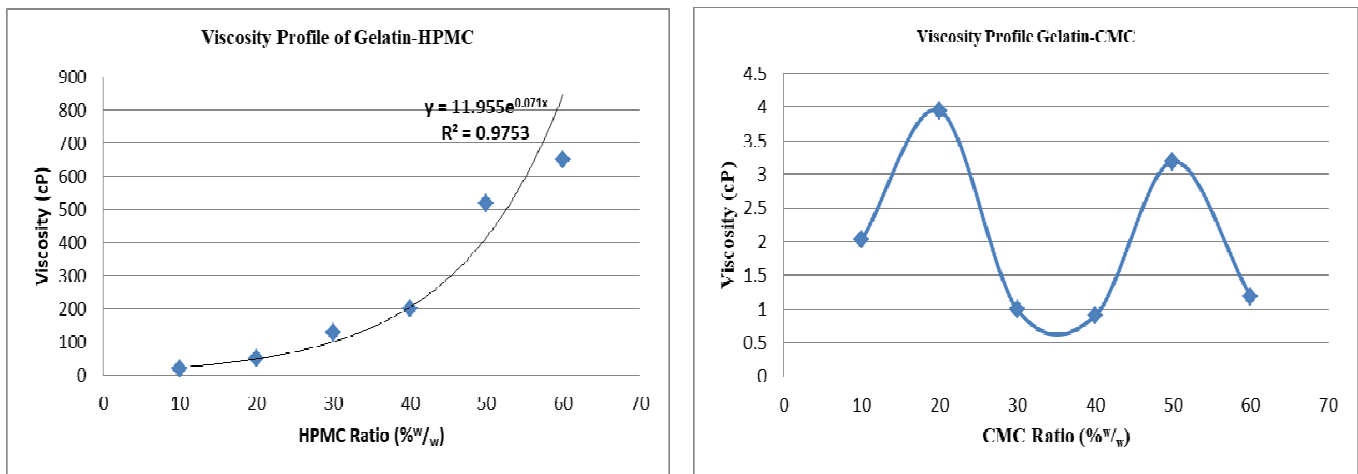
Figure 1. Viscosity Profile of Gelatin-HPMC Figure 2. Viscosity Profile of Gelatin-CMC Table 2. Characteristics of modified Gelatin

\begin{tabular}{|c|c|c|c|c|c|c|c|}
\hline \multirow[b]{2}{*}{ No } & \multirow{2}{*}{$\begin{array}{l}\text { Modified } \\
\text { Gelatin } \\
\text { Code }\end{array}$} & \multicolumn{3}{|c|}{ Organoleptic } & \multirow{2}{*}{$\begin{array}{l}\text { Elasticity } \\
\text { yes (y)/no } \\
\text { (n) }\end{array}$} & \multirow{2}{*}{\multicolumn{2}{|c|}{$\begin{array}{l}\text { Viscosities } \\
\quad \text { (cp) }\end{array}$}} \\
\hline & & Color & Texture & Odor & & & \\
\hline 1 & $\mathrm{G}_{\mathrm{SH} 10}$ & yellowish & $\begin{array}{c}\text { smooth, } \\
\text { transparent, sticky }\end{array}$ & $\begin{array}{l}\text { smooth } \\
\text { fishy }\end{array}$ & $\mathrm{y}$ & 20 & \\
\hline 2 & $\mathrm{G}_{\mathrm{SH} 20}$ & yellowish & $\begin{array}{c}\text { smooth, } \\
\text { transparent, sticky }\end{array}$ & $\begin{array}{l}\text { smooth } \\
\text { fishy }\end{array}$ & $\mathrm{y}$ & 50 & $\begin{array}{c}\text { Fish } \\
\text { Gelatin }\end{array}$ \\
\hline 3 & $\mathrm{G}_{\mathrm{SH} 30}$ & white & $\begin{array}{c}\text { smooth, } \\
\text { transparent, sticky }\end{array}$ & $\begin{array}{l}\text { smooth } \\
\text { fishy }\end{array}$ & $\mathrm{y}$ & 130 & $\begin{array}{c}(0.67 \%) \\
1.04\end{array}$ \\
\hline 4 & $\mathrm{G}_{\mathrm{SH} 40}$ & white & smooth, blur, sticky & $\begin{array}{l}\text { smooth } \\
\text { fishy }\end{array}$ & $\mathrm{y}$ & 200 & \\
\hline 5 & $\mathrm{G}_{\mathrm{SH} 50}$ & white & $\begin{array}{c}\text { bit rough, blur, } \\
\text { sticky }\end{array}$ & $\begin{array}{l}\text { smooth } \\
\text { fishy }\end{array}$ & $\mathrm{y}$ & 520 & HPMC \\
\hline 6 & $\mathrm{G}_{\mathrm{SH} 60}$ & white & $\begin{array}{l}\text { bit rough, blur, } \\
\text { sticky }\end{array}$ & $\begin{array}{c}\text { smooth } \\
\text { fishy }\end{array}$ & $\mathrm{y}$ & 650 & $(0.134 \%)$ \\
\hline 7 & $\mathrm{G}_{\mathrm{SC} 10}$ & yellowish & $\begin{array}{l}\text { smooth, } \\
\text { transparent, sticky }\end{array}$ & $\begin{array}{l}\text { smooth } \\
\text { fishy }\end{array}$ & $\mathrm{n}$ & 2.0286 & 206.66 \\
\hline 8 & $\mathrm{G}_{\mathrm{SC} 20}$ & yellowish & $\begin{array}{c}\text { smooth, } \\
\text { transparent, sticky }\end{array}$ & $\begin{array}{l}\text { smooth } \\
\text { fishy }\end{array}$ & $\mathrm{n}$ & 3.9439 & CMC \\
\hline 9 & $\mathrm{G}_{\mathrm{SC} 30}$ & yellowish & $\begin{array}{c}\text { smooth, } \\
\text { transparent, sticky }\end{array}$ & no smell & $\mathrm{n}$ & 0.995 & $(0.134 \%)$ \\
\hline 10 & $\mathrm{G}_{\mathrm{SC} 40}$ & yellowish & smooth, blur, sticky & no smell & $\mathrm{n}$ & 0.9017 & 7 \\
\hline 11 & $\mathrm{G}_{\mathrm{SC} 50}$ & yellowish & smooth, blur, sticky & no smell & $\mathrm{n}$ & 3.1929 & $0.044 /$ \\
\hline 12 & $\mathrm{G}_{\mathrm{SC} 60}$ & yellowish & smooth, blur, sticky & no smell & $\mathrm{n}$ & 1.1876 & \\
\hline 13 & $\mathrm{G}_{\mathrm{AS} 10}$ & brownish & smooth, blur, sticky & no smell & $\mathrm{n}$ & 1.146 & Potato \\
\hline 14 & $\mathrm{G}_{\mathrm{AS} 20}$ & brownish & smooth, blur, sticky & no smell & $\mathrm{n}$ & 1.122 & starch \\
\hline 15 & $\mathrm{G}_{\mathrm{AS} 30}$ & brownish & smooth, blur, sticky & no smell & $\mathrm{n}$ & 1.213 & $(0.67 \%)$ \\
\hline 16 & $\mathrm{G}_{\mathrm{AS} 40}$ & brownish & smooth, blur, sticky & no smell & $\mathrm{n}$ & 1.105 & \\
\hline
\end{tabular}




\begin{tabular}{|c|c|c|c|c|c|c|c|}
\hline 17 & $\mathrm{G}_{\mathrm{AS} 50}$ & yellowish & smooth, blur, sticky & no smell & $\mathrm{n}$ & 1.142 & 1.1390 \\
\hline 18 & $\mathrm{G}_{\mathrm{AS} 60}$ & yellowish & smooth, blur, sticky & no smell & $\mathrm{n}$ & 1.079 & \\
\hline 19 & $\mathrm{G}_{\mathrm{AK} 10}$ & brownish & smooth, blur, sticky & $\begin{array}{c}\text { smooth } \\
\text { fishy }\end{array}$ & $\mathrm{n}$ & 1.165 & \\
\hline 20 & $\mathrm{G}_{\mathrm{AK} 20}$ & brownish & smooth, blur, sticky & $\begin{array}{c}\text { smooth } \\
\text { fishy }\end{array}$ & $\mathrm{n}$ & 1.148 & $\begin{array}{c}\text { Cassava } \\
\text { starch }\end{array}$ \\
\hline 21 & $\mathrm{G}_{\mathrm{AK} 30}$ & brownish & smooth, blur, sticky & no smell & $\mathrm{n}$ & 1.175 & $(0.67 \%)$ \\
\hline 22 & $\mathrm{G}_{\mathrm{AK} 40}$ & brownish & smooth, blur, sticky & no smell & $\mathrm{n}$ & 1.068 & 1.2770 \\
\hline 23 & $\mathrm{G}_{\mathrm{AK} 50}$ & yellowish & smooth, blur, sticky & no smell & $\mathrm{n}$ & 1.013 & \\
\hline 24 & $\mathrm{G}_{\mathrm{AK} 60}$ & yellowish & smooth, blur, sticky & no smell & $\mathrm{n}$ & 1.069 & \\
\hline 25 & $\mathrm{G}_{\mathrm{AM} 10}$ & brownish & smooth, blur, sticky & $\begin{array}{c}\text { smooth } \\
\text { fishy }\end{array}$ & $\mathrm{n}$ & 1.250 & \\
\hline 26 & $\mathrm{G}_{\mathrm{AM} 20}$ & brownish & smooth, blur, sticky & $\begin{array}{c}\text { smooth } \\
\text { fishy }\end{array}$ & $\mathrm{n}$ & 1.149 & $\begin{array}{l}\text { Corn } \\
\text { starch }\end{array}$ \\
\hline 27 & $\mathrm{G}_{\mathrm{AM} 30}$ & brownish & smooth, blur, sticky & $\begin{array}{c}\text { smooth } \\
\text { fishy }\end{array}$ & $\mathrm{n}$ & 1.172 & $(0.67 \%)$ \\
\hline 28 & $\mathrm{G}_{\mathrm{AM} 40}$ & yellowish & smooth, blur, sticky & no smell & $\mathrm{n}$ & 1.141 & 1.1420 \\
\hline 29 & $\mathrm{G}_{\mathrm{AM} 50}$ & yellowish & smooth, blur, sticky & no smell & $\mathrm{n}$ & 1.211 & \\
\hline 30 & $\mathrm{G}_{\mathrm{AM} 60}$ & yellowish & smooth, blur, sticky & no smell & $\mathrm{n}$ & 1.141 & \\
\hline
\end{tabular}

The viscosity of Gelatin-HPMC increased with increasing ratio, while viscosity profile following the exponential equation (figures 1 and 3) and the value of viscosity differed very significantly $(\mathrm{p}<0.05)$ between groups. With the value and viscosity profile of gelatin-HPMC also at a concentration of $0.1 \%$ to $2 \%$ (gelatin HPMC $(2.5: 2.5)$ by showing the value that can be used for the manufacture of controlled drug delivery matrix system. Organoleptic characteristics such as elastic and stickiness of this modified gelatin show properties that can be utilized for drug alert systems in the form of patch mucoadhesive.

Viscosity profile of gelatin-CMC showed that an increase in the CMC ratio did not provide increased viscosity as well. This showed there was an optimum concentration of CMC that can 
bind to gelatin, and vice versa. A CMC increase of up to $60 \%$ remains unable to provide a good viscosity of the composite (Figure 2).Gelatin-CMC 4: 1 showed the best viscosity that was Viscosity profiles of some concentrations of modified gelatin-CMC (4:1) is shown in Figure 4A. A concentration of $0.5 \%$ to $4 \%$ has a viscosity value that increases logarithmically with a viscosity value that can be used as a thickening agent in liquid, solid and semi-solid preparations for the food and pharmaceutical industries. While concentrations of $6 \%$ and above show a linearly increasing concentration profile, but the value of this viscosity makes it possible to be utilized as a matrix material for controlled drug remedial control systems by looking at its ability to develop and retain water.

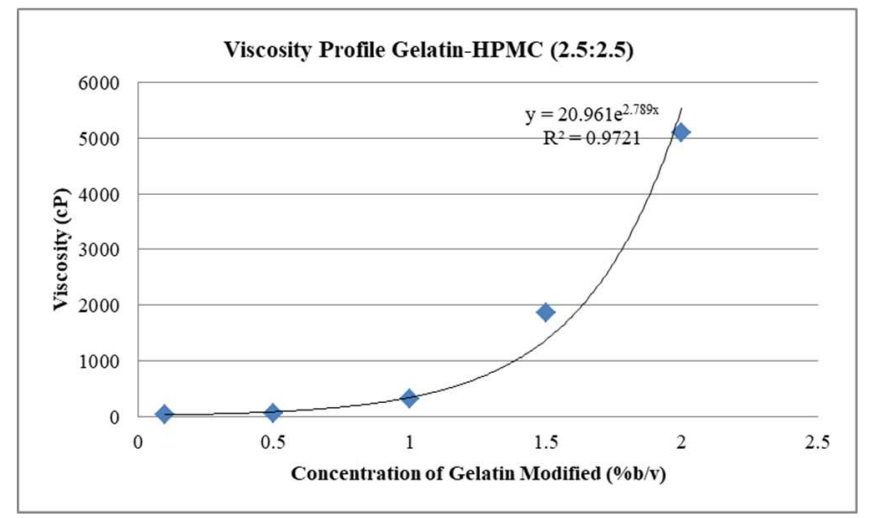

Figure 3. Viscosity Profile of Gelatin-HPMC (2.5:2.5)
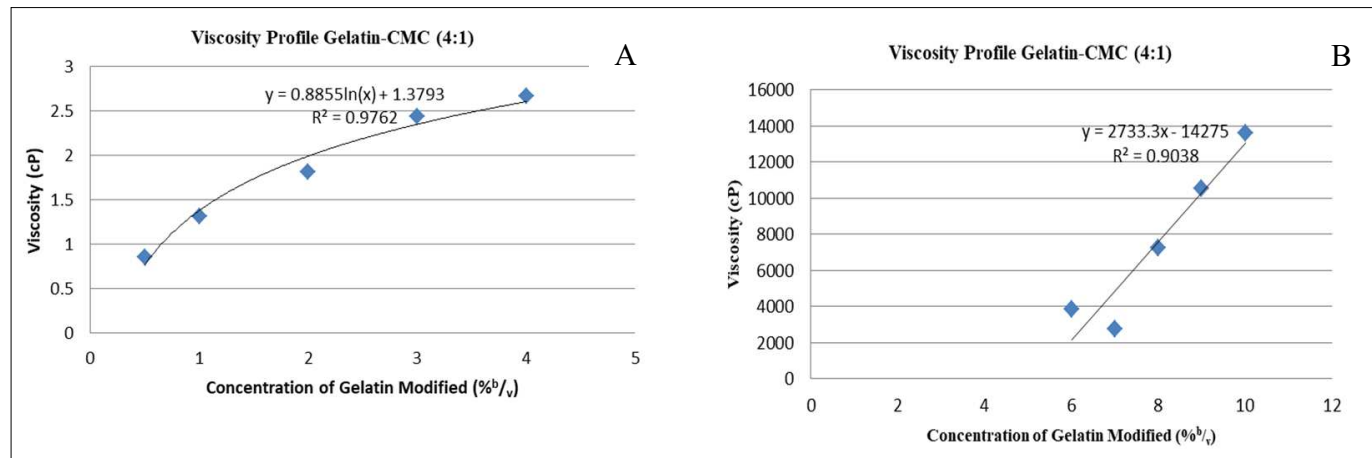

Figure 3. Viscosity Profile of Gelatin-CMC (4:1) $0.5 \%-4 \%$ 

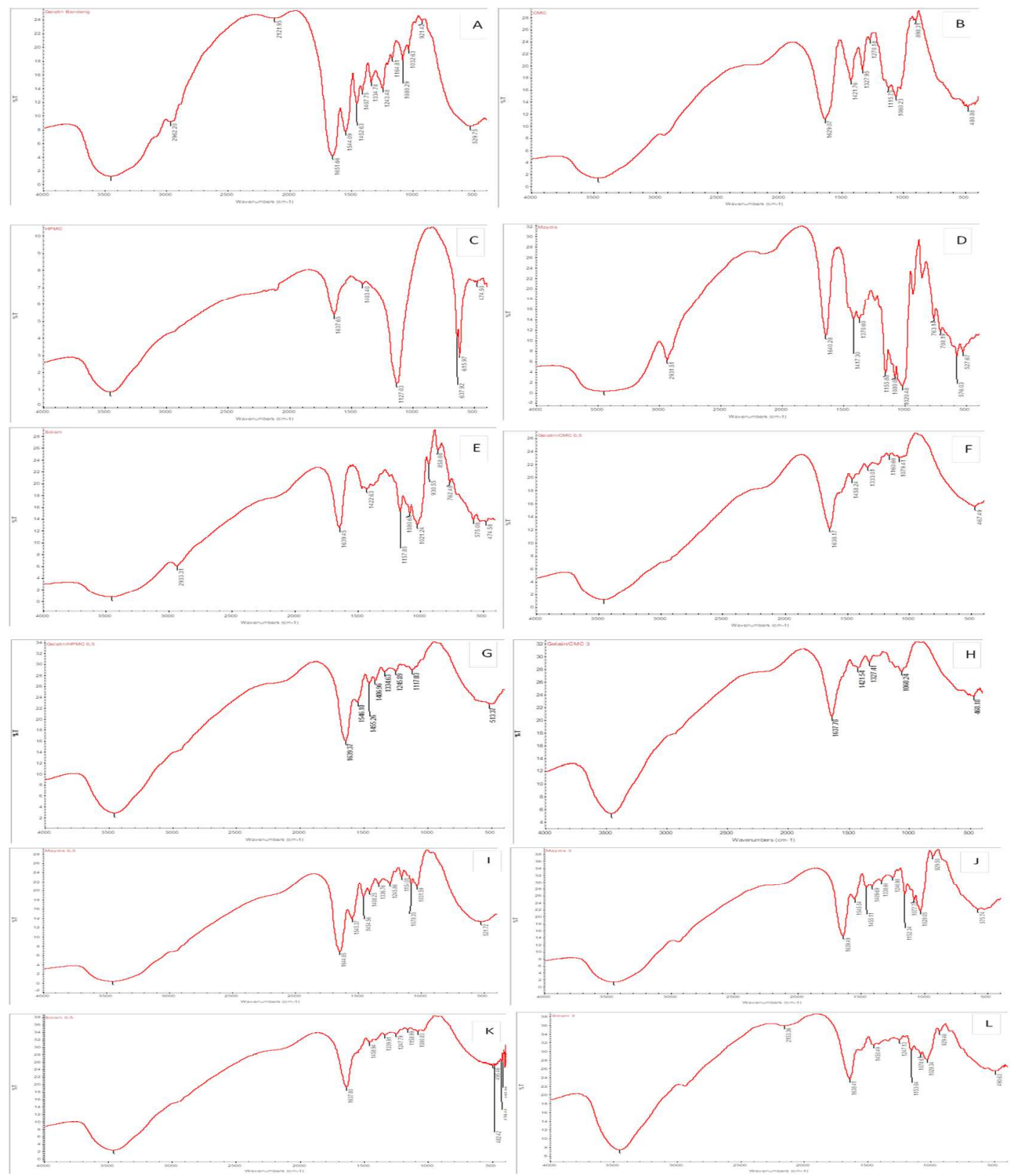

Figure 5.IR Spectra of Polymers.Gelatin (A), CMC (B), HPMC (C), Corn Starch (D), Potato Starch (E), Gelatin-CCMC (F,H), Gelatin-HPMC (G), Gelatin-Corn Starch (I,J) and GelatinPotato Starch $(\mathrm{K}, \mathrm{L})$ 


\section{Conclusion}

Gelatin, which is modified through chemical interaction with CMC and HPMC cellulose, can improve its characteristics, especially on the increase in viscosity and elasticity and stickiness. Chemical interactions that occur in gelatin modified with cellulose and starch show interactions in carboxylic groups especially in the hydroxyl group and in the amine group shown by a shift in wavenumber. The GS modification results in better gel quality than GA. The viscosity profile of GS increases with increasing cellulose levels. GSI\& GS2 has the potential to be used as a thickener for liquid, solid and semi-solid foods and pharmaceutical preparations (syrup, suspension, and emulsion) and semi-solids (gel, cream, paste) while GS3, GS4, GS5, and GS6 can be used as a controlled release drug matrix and drug delivery system.

Acknowledgments

We are very grateful for the support provided by the Ministry of Religion of the Republic of Indonesia through research grants and PT Usaha Centraljaya Sakti, South Sulawesi, Indonesia that gave us raw material milkfish scales.

\section{References}

[1] M. Abd Elgadir, M. E. S. Mirghani, and A. Adam, "Fish gelatin and its applications in selected pharmaceutical aspects as alternative source to pork gelatin," J. Food, Agric. Environ., vol. 11, no. 1, pp. 73-79, 2013, doi: 10.1016/j.ijrobp.2009.09.077.

[2] M. C. Gomez-Guillen, B. Gimenez, M. E. Lopez-Caballero, and M. P. Montero, "Functional and bioactive properties of collagen and gelatin from alternative sources: A review," Food Hydrocoll., vol. 25, no. 8, pp. 1813-1827, 2011, doi: 10.1016/j.foodhyd.2011.02.007.

[3] S. Benjakul, P. Kittiphattanabawon, and J. M. Regenstein, Fish Gelatin, 1st ed., vol. 60, no. 10. Elsevier Inc., 2012.

[4] M. Sompie, A. D. Mirah, and L. C. H. M. Karisoh, "Pengaruh perbedaan suhu ekstraksi terhadap karakteristik gelatin kulit kaki ayam Effect of extraction temperature difference on characteristics of chicken leg skin gelatin," vol. 1, pp. 792-795, 2015, doi: $10.13057 / \mathrm{psnmbi} / \mathrm{m} 010420$.

[5] I. J. Haug, K. I. Draget, and O. Smidsrød, "Physical and rheological properties of fish gelatin compared to mammalian gelatin," Food Hydrocoll., vol. 18, no. 2, pp. 203-213, 2004, doi: 10.1016/S0268-005X(03)00065-1.

[6] D. M. Correia, J. Padrão, L. R. Rodrigues, F. Dourado, S. Lanceros-Méndez, and V. Sencadas, "Thermal and hydrolytic degradation of electrospun fish gelatin membranes," Polym. Test., vol. 32, no. 5, pp. 995-1000, 2013, doi: 10.1016/j.polymertesting.2013.05.004. 
[7] H. L. Fuchsbauer, U. Gerber, J. Engelmann, T. Seeger, C. Sinks, and T. Hecht, "Influence of gelatin matrices crosslinked with transglutaminase on the properties of an enclosed bioactive material using $\beta$-galactosidase as model system," Biomaterials, vol. 17, no. 15, pp. 1481-1488, 1996, doi: 10.1016/0142-9612(96)89772-9.

[8] A. Duconseille, T. Astruc, N. Quintana, F. Meersman, and V. Sante-Lhoutellier, "Gelatin structure and composition linked to hard capsule dissolution: A review," Food Hydrocoll., vol. 43, pp. 360-376, Jan. 2015, doi: 10.1016/j.foodhyd.2014.06.006.

[9] J. Maitra and V. K. Shukla, "Cross-linking in Hydrogels - A Review," Am. J. Polym. Sci., vol. 4, no. 2, pp. 25-31, 2014, doi: 10.5923/j.ajps.20140402.01.

[10] M. Araghi, Z. Moslehi, A. Mohammadi Nafchi, A. Mostahsan, N. Salamat, and A. Daraei Garmakhany, "Cold water fish gelatin modification by a natural phenolic cross-linker (ferulic acid and caffeic acid)," Food Sci. Nutr., vol. 3, no. 5, pp. 370-375, 2015, doi: $10.1002 /$ fsn 3.230 .

[11] B. Sen Chiou et al., "Cold water fish gelatin films: Effects of cross-linking on thermal, mechanical, barrier, and biodegradation properties," Eur. Polym. J., vol. 44, no. 11, pp. 3748-3753, 2008, doi: 10.1016/j.eurpolymj.2008.08.011.

[12] G. A. Denavi, M. Pérez-Mateos, M. C. Añón, P. Montero, A. N. Mauri, and M. C. GómezGuillén, "Structural and functional properties of soy protein isolate and cod gelatin blend films," Food Hydrocoll., vol. 23, no. 8, pp. 2094-2101, 2009, doi: 10.1016/j.foodhyd.2009.03.007.

[13] M. Foox and M. Zilberman, "Drug delivery from gelatin-based systems," Expert Opin. Drug Deliv., vol. 12, no. 9, pp. 1547-1563, 2015, doi: 10.1517/17425247.2015.1037272.

[14] G. Boran and J. M. Regenstein, "Optimization of gelatin extraction from silver carp skin," J. Food Sci., vol. 74, no. 8, pp. 432-441, 2009, doi: 10.1111/j.1750-3841.2009.01328.x. 